Chapman University

Chapman University Digital Commons

Philosophy Faculty Articles and Research

Philosophy

3-2-2012

\title{
Reconciling Justice and Pleasure in Epicurean Contractarianism
}

John Thrasher

Chapman University, thrasheriv@chapman.edu

Follow this and additional works at: https://digitalcommons.chapman.edu/philosophy_articles

Part of the Ethics and Political Philosophy Commons, and the Other Philosophy Commons

\section{Recommended Citation}

Thrasher, John. "Reconciling Justice and Pleasure in Epicurean Contractarianism." Ethical Theory \& Moral Practice, vol. 16, no. 2, 2013, pp. 423-436. doi: 10.1007/s10677-012-9348-5

This Article is brought to you for free and open access by the Philosophy at Chapman University Digital Commons. It has been accepted for inclusion in Philosophy Faculty Articles and Research by an authorized administrator of Chapman University Digital Commons. For more information, please contactlaughtin@chapman.edu. 


\section{Reconciling Justice and Pleasure in Epicurean Contractarianism}

\section{Comments}

This is a pre-copy-editing, author-produced PDF of an article accepted for publication in Ethical Theory o Moral Practice, volume 16, issue 2, in 2013 following peer review. The final publication is available at Springer via DOI: $10.1007 / \mathrm{s} 10677-012-9348-5$.

\section{Copyright}

Springer 


\title{
Reconciling Justice and Pleasure in
}

\section{Epicurean Contractarianism}

\author{
John Thrasher \\ University of Arizona \\ Johnthrasher23@gmail.com
}

\begin{abstract}
Epicurean contractarianism is an attempt to reconcile individualistic hedonism with a robust account of justice. The pursuit of pleasure and the requirements of justice, however, have seemed to be incompatible to many commentators, both ancient and modern. It is not clear how it is possible to reconcile hedonism with the demands of justice. Furthermore, it is not clear why, even if Epicurean contractarianism is possible, why it would be necessary for Epicureans to endorse a social contract. I argue here that Epicurean contractarianism is both possible and necessary once we understand Epicurean practical rationality in a new way. We are left with an appealing version of teleological, individualistic contractarianism that is significantly different from Hobbesian contractarianism.
\end{abstract}

Keywords: Epicurus, Social Contract, Lucretius, Mixed-Motive Games, Stag

Hunt,

\section{The Epicurean Reconciliation Project}

Epicurean contract theory represents a unique and important tradition in both the history of the social contract and western political thought generally. Although not well known among political and moral theorists, it is significantly different from what Jean Hampton has called the two, Kantian and Hobbesian, faces of contract theory (Hampton 1991). Epicurean contract theory is unique in its attempt to reconcile the individual's pursuit of pleasure and tranquility with the public need for justice and peace.

This Epicurean "reconciliation project" is distinguished from the Hobbesian project of reconciling private prudence with public morality in several 
instructive ways. $^{1}$ Justice, for the Epicurean, secures the natural need for tranquility and happiness $(K D 31) .^{2}$ While the Epicurean has a positive goal for contracting, the Hobbesian has an essentially negative goal for entering contractual society. The Hobbesian sees the social contract as a way to end the war of all against all in the state of nature (Hampton 1988, chap. 2). The Epicurean is motivated to enter contractual society in order to secure happiness and cooperation, whereas the Hobbesian seeks to avoid war. Furthermore, it is fear, particularly the fear of violent death, which motivates the Hobbesian. Without this fear, the Hobbesian would not be motivated to seek or maintain the social contract. The Epicurean, however, aims to eliminate the fear of death in order to achieve tranquility and peace (Mitsis 1988, p. 67). These differences make the Epicurean social contract distinct in interesting ways from its Hobbesian cousin. Epicurean contractarianism is a non-Hobbesian teleological account of justice. Those who are attracted to teleological theories of practical rationality and contractual theories of justice will find Epicurean contractarianism appealing.

This version of contractarianism is also interesting because it was so unusual. Among the major ancient philosophers, the idea of the social contract was often used as a example of a "a pernicious error" to be attacked (Vlastos 1941, p. 291). Indeed, according to Gough, "much of the political philosophy of

\footnotetext{
${ }^{1}$ Here I am drawing on Gregory Kavka’s “reconciliation project.” See: (Kavka 1984; Kavka 1986).

${ }^{2}$ In the following pages KD refers to Kuria Doxa or Principle Doctrines, VS refers to Vatican Sayings, and Ep. Men. refers to the Letter to Menoeceus. All references are from The Epicurus Reader translation by Inwood and Gerson. See: (Inwood and Gerson 1994).
} 
Plato and Aristotle was designed to combat these subversive opinions [of the social contract]" (Gough 1957, p. 13). Justice understood as a contract concerned many ancient thinkers because, on this view, justice has a merely instrumental value useful for securing individual benefits in social intercourse. If justice is valued only because of the benefits it confers, what is to stop citizens from deserting justice when its benefits outweigh its costs? Political society can never truly be secure on such selfish, individualistic grounds, as many ancient thinkers argued. Epicureans, then, insofar as they hold an instrumental conception of justice can never be truly trustworthy members of society; they can never be good citizens. ${ }^{3}$ Critics contend that Epicureanism is a counter-cultural and subversive political doctrine (Brown 2009, p. 180). This charge raises the question of how an Epicurean can be a reliable member of political society. How is hedonism compatible with justice, they wonder. The answer to both of these questions will determine whether the Epicurean project of reconciling the pursuit of private pleasure with public justice is possible.

The traditional answer to this question has been that attempting to build the bonds of civic allegiance on a foundation of individualistic hedonism is hopeless. Commenting on Hobbes's similar project, David Gauthier notes that "from unlimited individualism only anarchy follows" (Gauthier 1969, p. vi). While I agree with Gauthier and other critics that the Hobbesian reconciliation

\footnotetext{
${ }^{3}$ A similar question arises, for similar reasons, with regard to the Epicureanism and friendship. This paper is not directly concerned either with the possibility of Epicurean citizenship or friendship, except incidentally in $\S 2$. For excellent recent work on the topic of the possibility and nature of Epicurean friendship see: (O’Keefe 2001a) and (Evans 2004).
} 
project has severe problems, I will argue here that the Epicurean project to reconcile private benefit with public stability has promise. If I am right, the Epicurean approach to contractual justice will provide a much needed alternative to the traditional approaches to contract theory that come from Hobbes and Kant. These different features of the Epicurean social contract will then not only interest classical scholars, but also contemporary contract theorists who are concerned with using the social contract to mediate between private and public reason. To that end, I aim to show here that the Epicurean conception of the social contract is appealing on its own terms and of interest to contemporary contract theorists.

To show that justice and pleasure can be reconciled is to show that the non-teleological demands of justice are consistent with the teleological dictates of hedonistic practical rationality. In $\S 2$, I argue that we should think of the Epicurean hedonic calculus as applying, at least some of the time, to rules rather than directly to actions or desires. Once we understand Epicurean practical rationality as a kind of "rule-hedonism," I argue in $\S 3$, it is possible to show that contractual justice is consistent with Epicurean practical rationality. Even if the social contract is possible, the question remains whether it is necessary. Do Epicureans really need a social contract or is first-personal practical rationality enough for tranquility? In $\S 4$ I argue that even a society of perfectly wise Epicureans would need public rules of justice to preform coordinating, assuring, and specifying functions. I close by arguing, in $\S 5$, that Epicurean contractarianism is not only possible and useful, but also attractive. 


\section{Epicurean Practical Rationality}

Showing that Epicurean teleological hedonism is consistent with the nonteleological demands of justice is the key to the Epicurean reconciliation project. Epicurean practical rationality is teleological in that all reasoning aims at the goal of ataraxia. The demands of justice are non-teleological in that they are not justified on how well they help satisfy some further aim. In this section, I argue that we need to understand Epicurean hedonism as applying to rules rather than actions or desires for this reconciliation to work. First, I show the general contours of Epicurean hedonism. Then I highlight some of the problems that arise in relation to friendship, before arguing for a solution to these problems that I call "rule-hedonism."

Epicurean contractarianism, like all Epicurean thought, is the consequence of one fundamental motivational principle:

If you do not, on every occasion, refer each of your actions to the goal of nature, but instead turn prematurely to some other [criterion] in avoiding or pursuing [things], your actions will not be consistent with your reasoning. (KD 25)

This goal of reasoning and action is the absence of pain and the tranquility that comes from living without fear $(K D 3) .{ }^{4}$ This kind of pleasure, ataraxia, is

\footnotetext{
${ }^{4}$ Throughout I will use the terms "ataraxia" "pleasure" "tranquility" and "happiness" as synonyms unless noted otherwise.
} 
unhindered tranquility, rather than a sensation of active pleasure. ${ }^{5}$ It is a psychological fact, according to Epicurus, that we do actually seek ataraxia and that our lives go best, from a subjective point of view, when we pursue ataraxia. It is the natural goal of beings like us. If fear of the gods, death, and pain constitute sickness of the soul, removing those ailments constitutes its health. This psychological hedonism creates the justification for the normative hedonism that practical reasoning should aim at ataraxia. ${ }^{6}$ The normative ideal of Epicurean practical rationality is a hedonistic form of instrumental rationality with the final end of ataraxia. In the parlance of modern decision theory, it is a maximizing theory of rationality. Given a set of ordered preferences, individuals chose rationally when they choose to act on their highest valued goals. To choose less pleasure rather than more pleasure when given the choice is paradigmatically irrational and contrary to nature.

Given this conception of practical rationality and virtue it is hard to see how one can single-mindedly pursue pleasure and accept the constraints of justice. Traditionally, virtue ethical theories solve this problem by making the virtue of justice constitutive of happiness with deontic restraints built into the formal conditions of happiness. ${ }^{7}$ To use the Rawlsian terminology, the right flows naturally out of the good. ${ }^{8}$ This solution, however, will not work for the

\footnotetext{
${ }^{5}$ Here I am following (Nikolsky 2001).

${ }^{6}$ Again, there is some controversy on this point, but I find Nikolsky's argument persuasive. See: (Nikolsky 2001).

${ }^{7}$ For an interesting and sophisticated recent treatment of this problem, see: (LeBar 2009).

${ }^{8}$ Of course, it is easy to overstate this point. Julia Annas cautions against drawing too much of a wedge between the ancients and the moderns on this point. See: (Annas 1993, chap. 13).
} 
Epicurean. Unlike in Aristotelian or Stoic virtue theory, the standard of Epicurean happiness is not an objective, formal standard, but rather the subjective, psychological state of ataraxia. The Epicurean has a reason to $\phi$ only if he or she believes that $\phi$-ing will reliably lead to the final end of ataraxia. If all reasons are instrumental in this sense, how is it possible for the Epicurean to have reason to constrain his or her pursuit of the goal of nature by the deontic demands of justice? To give a plausible account of justice, the Epicurean needs to explain how to justify the demands of justice as a means to the final end of ataraxia.

One version of this problem arises in the context of friendship. Epicurus claims "...every friendship is worth choosing for its own sake, though it takes its origin from the benefits it confers on us" (VS 23). Given this statement about the value of friendship and $K D 25$, how can friendship be non-instrumentally valuable while also being beneficial because of the benefit it confers? Some have argued that genuine friendship is impossible unless we amend the basic egoistic element of Epicurean practical rationality. ${ }^{9}$ In contrast, Matt Evans argues that there are two basic approaches to understanding friendship in a consistently egoistic way (Evans 2004, 413). Friendship as "indirect egoism" involves incorporating the good of a friend or of friendship generally into one's own good. This is the interpretation that Timothy O'Keefe favors (O'Keefe 2001a). The alternative is Evans's preferred view, "direct egoism," that one's own good "stands or falls" with the good of one's friend (Evans 2004, 413). Indirect egoism is, for O'Keefe, a two-level hedonistic theory. Choice of desires is governed directly by hedonic concerns and those desires then pick out particular actions, which are only

\footnotetext{
${ }^{9}$ See, for instance (Mitsis 1988, 98-128) and (Annas 1993, 236-244).
} 
indirectly related to the original hedonic calculus (O'Keefe 2001a, 300-302). In contrast, Evans's direct egoism applies the hedonic calculus to action selection. Evans maintains that Epicureans can "reason their way to friendship" through direct egoistic means (Evans 2004, 423). What is true of friendship will likely be true of justice so it is imperative to determine whether the Epicurean hedonic calculus is meant to apply to actions (direct egoism), desires (indirect egoism), or something else entirely. The direct egoism interpretation has the benefit of being the easiest to reconcile with $K D 25$. The indirect egoist interpretation makes it easier to understand how the Epicurean can incorporate friendship and justice into hedonism. Another possibility, between direct and indirect egoism, is what Gregory Kavka calls "rule egoism" (Kavka 1986, chap. 9). Although Kavka developed his version of rule egoism in the context of understanding Hobbes's ethical theory, there are enough similarities between the two accounts for a plausible Epicurean version as well. The hedonic calculus applies directly to rules rather than to desires or action. Furthermore, rules can be generalizations over desires or actions, e.g. "don't cultivate a desire for riches" or "seek out friends." The first is a rule that indicates what desires will lead to pleasure whereas the second is a rule that indicates a particular set of actions that will likely lead to pleasure, namely having friends.

Rule egoism has several benefits over direct and indirect egoism. First, it is more general. Both actions and desires are mentioned throughout $K D$ and $V S$ as the possible object of choice. Rule egoism recognizes the importance of both actions and desires to the end of ataraxia and accounts for both in terms of rules. Second, rule egoism is simpler and likely more reliable than direct or indirect 
egoism. It is reasonable to expect that the typical Epicurean would be bewildered in the face of the multiplicity and complexity of choices that would face him or her on any given day. The stress of deliberating over actions on the direct egoist interpretation of $K D 25$ would often create anxiety rather than tranquility. Similarly, it is not clear that, given the complexity of the world, the direct approach would reliably lead to ataraxia. The indirect approach is not better on this count partly because desires do not necessarily pick out unique action in decision situations, partly because the indirect egoist faces the same problem as the direct egoist at the level of desires. By using rules, however, the Epicurean can rely on the knowledge embodied in the rules without having to deliberate in each case.

This explains the reason that Epicurus spends so much time in his writing listing rules and maxims. He gives rules about how to reduce sexual passion (VS 18), the irrationality of suicide (VS 38), the danger of envy (VS 53), and the dangers of great wealth (VS 67). In all of these cases, and many more, Epicurus is passing on wisdom about how to reliably achieve ataraxia. He is playing the part, as it were, of a guide who has walked down life's tangled road and is reporting to those who have yet to see everything he has seen. These maxims or rules are the embodiment of the successful use of practical rationality in the past. Following these types of rules is, therefore, an application of direct egoism in an indirect way. Given the limited cognitive capacity and time of the Epicurean rational agent, relying on rules as a guide can be, following Gigerenzer and Goldstein, a "fast and frugal" way of reasoning based on heuristics communicated as rules or maxims (Gigerenzer and Goldstein 1996). Instead of choosing over the expected 
outcome of individual acts, the rule egoist chooses sets of rules to follow based on the expected outcome of following that rule or set of rules (Kavka 1986, 358359). In the next section we will see how understanding Epicurean practical rationality as "rule-hedonism" makes it possible to reconcile Epicurean practical rationality with justice.

\section{The Possibility of the Contract}

Once we understand Epicurean practical rationality as applying to rules rather than to particular actions or desires, we can see how the Epicurean can reconcile the imperatives of practical rationality with the demands of justice. A particular social contract is a set of rules that regulates behavior in certain public settings. The Epicurean agrees to a particular set of rules in order to more reliably achieve and maintain personal ataraxia. We might wonder, however, why the Epicurean would need a contract at all. Why wouldn't the first-personal application of practical rationality be sufficient for ataraxia? Why is the social contract necessary? In a world of practically rational Epicureans, the social contract seems either otiose or harmful. Either the contract recommends what practical rationality would recommend or it conflicts with practical rationality. On its face, Epicurean contractarianism looks either unnecessary or impossible. I will argue here that the Epicurean social contract is both necessary and possible. The social contract is necessary, as I will argue in the next section, for its coordinating, assuring, and specifying functions. The social contract is possible because of the role that rules can play in Epicurean practical rationality. In this section I will argue that the 
Epicurean social contract is consistent with Epicurean practical rationality and, hence, possible, while fulfilling an important social role.

The Epicurean social contract is fundamentally instrumental; it is a "pledge of reciprocal usefulness neither to harm one another nor be harmed" (KD 35). To be consistent with Epicurean practical rationality, then, the contract must secure benefits that would not be possible without the contract. If, however, one only has reason to enter into a contract because of the benefits, what reason does one have to follow the contract when there are no benefits and only costs? This is the heart of the concern that the Epicurean cannot be a good citizen. If citizenship involves the possibility of sacrifice, why should we expect the Epicurean to comply? Here again, we see the same kind of problem that we saw in $\$ 2$ concerning friendship; the solution is also similar.

A conflict between practical rationality and the requirements of justice arises when the connection between the rules of justice and individual benefit come apart. If someone is convinced that he or she will be able to avoid detection, there is no reason, one might fear, not to commit injustice. When benefit and justice conflict, so much the worse for justice. To solve this problem, we need to show that the rules of justice are an integral part of practical rationality and so rules of justice will not conflict with practical rationality, rightly understood.

To see how this integration is possible consider a case from Book II of De Finibus. ${ }^{10}$ Cicero's challenges Torquatus with two situations where acts of injustice lead to substantial benefits. In one case, a man leaves his estate to his

\footnotetext{
${ }^{10}$ All references to De Finibus are from the 2001 edition edited by Julia Annas and translated by Raphael Woolf. See: (Cicero 2001).
} 
friend in trust for his daughter. Once the man is dead, his friend lacks a prudential reason for keeping his word to hold the estate in trust (De Fin, II 58). In a second case, Cicero supposes an Epicurean knows “...that a viper is lurking somewhere, and that someone whose death would benefit you is about to sit down on it unawares" (De Fin, II 59). If no one is around, it is hard to see why the Epicurean would warn the person about the snake. The question is whether the Epicurean, in cases like these, will be reliably just.

Torquatus argues that the Epicurean would naturally feel guilty after doing wrong and, hence, would avoid doing it in the first place. Knowing their own psychological make-up, the Epicurean will avoid acting unjustly so as to avoid the guilt, remorse, stress, and other negative emotions that come from hurting others and acting unjustly. Cicero, unconvinced, replies that when dealing with a "sly fox" without remorse, this response will be impotent. The Epicurean, according to Cicero, is begging the question by claiming that there will never be any temptation to behave improperly in the first place. In effect, the Epicurean is denying that benefit and justice can ever conflict. Similarly, the Epicurean might also reply, as Torquatus does in Book I that, "however secret the deed, there is never a guarantee that it will remain secret" (De Fin, I 50). This is also presumably true, but it seems to miss something important in the Ciceronian challenge. Cicero, like Glaucon is arguing that there are at least some cases where benefit and justice will recommend different actions, since Epicurean practical rationality is based on benefit, to act justly in cases where justice conflicts with benefit is to act irrationally. 
The Epicurean, however, can respond to these concerns once we understand the role of rules in Epicurean practical rationality. We saw in $\$ 2$ that rule following is often more reliable than individual action evaluation in achieving pleasure. Rules constrain the teleological pursuit of the good, but only as a means of more reliably achieving more good. The Epicurean is trying to optimize on ataraxia given the constraints of justice, just as a rational economizer in the market will try to optimize on value given the hard budget constraints they may have. ${ }^{11}$ In the same way that a budget constraint for a household will rule out some valuable purchases, over time it will ensure the solvency of the household. Justice, to the rational Epicurean, is similar; it restricts individual choices in the short-run, but increases the reliability of achieving pleasure in the long-run. Justice constrains action at the local level as a means to global optimizing of ataraxia. Rules play this role in the Epicurean conception of justice by specifying publicly stable and recognized action directives.

Following the contractual rules of justice is also a prudent strategy for those, like the Epicurean, who are primarily concerned with tranquility. Epicurus writes that, "the just life is most free from disturbance, but the unjust life is full of the greatest disturbance" (KD 17). Epicurus is arguing that following the rules of justice is a key component of the tranquil life. No one who disobeys the rules of justice can be certain that they will be able to avoid detection from their wrongdoing. This uncertainty causes anxiety. Anxiety is the opposite of

\footnotetext{
11 The obvious analogy is to linear programming and maximization given constraint, where the constraint here is the contractarian rules of justice. For an example how constraints are applied to practical rationality that is similar to the account offered here, see: (Schmidtz 1992).
} 
tranquility. This is much the same response that Hume gives to the sensible knave when he admits that someone who is not disposed to follow the rules of justice cannot be easily convinced of their worth, but that those who are disposed to act justly open themselves to "...inward peace of mind" (EPM, 9.22). ${ }^{12}$ The wise Epicurean will not gamble on the probability of getting away with injustice in each act but will follow the rules of justice instead. Wisdom is the unwillingness to gamble in these situations.

Once we see that justice can be part of a means to the end of globally optimizing on ataraxia, it is worth taking another look at earlier challenges raised by Glaucon and Cicero. The Lydian shepherd, with the Ring of Gyges, has the ability to commit any crime without fear of reprisal. This power to commit injustice without the fear of reprisal makes the shepherd "an equal to a god among humans" (Republic, 360c). ${ }^{13}$ Glaucon wants Socrates to demonstrate that even the Lydian shepherd has reason to be just, but Glaucon is surely asking for the impossible. As both Epicurus and Hume suggest, there can be no justice between gods and mortals or humans and animals (KD 32). Justice is a relationship between relative equals $(E P M, 3.18-21)$. Hume suggests that if there were a species so weak that they could never hope to harm us, we would not be able to treat them justly $(E P M, 3.18)$. Once the shepherd has the Ring, he is no longer in

\footnotetext{
${ }^{12}$ EPM is an abbreviation for The Enquiry Concerning the Principles of Morals. All citations are from the 1998 edition edited by Tom Beauchamp, see: (Hume 1998).

${ }^{13}$ All references to The Republic are from Bloom's 1968 translation. See: (Plato 1968).
} 
the circumstances of justice with his fellows. ${ }^{14}$ In these types of cases, the rules of justice do not reliably lead to ataraxia. The Epicurean realizes, however, that the actual world has a conspicuous lack of all-powerful magical rings. We do exist, for the most part, in the circumstances of justice and, hence, the rules of justice do tend to be reliable tools. Our fellows are roughly as powerful and frail as we are. As David Gauthier puts it, "human beings live, and must live, in the circumstances of justice" (Gauthier 1982, p. 27). Hobbes was right to think that however unequal humans may be in many respects, we are still roughly equal in the ability to harm one another (Leviathan, chap. 15). ${ }^{15}$ This means that whatever incidental asymmetries of power and resources that may arise, the circumstances of justice will remain.

In our world of approximate equality, Epicureans will have prudential reason to abide by the rules of justice as a means to ataraxia. The pursuit of the good is rationally constrained by principles of right so that one may more reliably achieve tranquility. ${ }^{16}$ By making the rules of justice an essential component of the

\footnotetext{
${ }^{14}$ Epicurus is unequivocal that justice is useful and that the purpose of justice is mutual, reciprocal benefit $(K D 31)$.

${ }^{15}$ References from Leviathan are from the 1996 Cambridge Revised Student Edition edited by Richard Tuck. See: (Hobbes 1996)

${ }^{16}$ There are obvious similarities between my account and the account in (Vander Waerdt 1987, p.408-411). One main difference, though, is that I am dealing with the question of whether it rational to follow the rules of justice in the normal, everyday case. That is, whether it can ever be rational to abide by the rules of justice when they conflict with what practical rationality would recommend if the case were judged on its own, without relation to the rules. Vander Waerdt is concerned primarily with the question of whether there are cases where the Epicurean will be
} 
prudent pursuit of ataraxia, we can see how it is possible for an Epicurean to be both practically rational and committed to the rules of justice. As a modern proponent of a kind of view argued, "duty overrides advantage, but the acceptance of duty is truly advantageous" (Gauthier 1986, p. 2). Naturally, this is only true if the rules of justice really do reliably lead to security and tranquility. The act of merely contracting, however, is not enough to ensure this. As Eric Brown notes, "Epicurus recognizes limitations on the substance of the convention," namely that the rules of justice actually do guarantee reciprocal usefulness and protection from harm (Brown 2009, p. 195). Brown also notes that the efficacy of the rules of justice will lead to different rules being acceptable in different times and places. Epicurus can provide a justificatory test of the rules of justice, that they are reciprocally useful and provide protection, but he cannot specify exact rules of justice that will be stable across different societies and different ages. This is how it should be. One of the key lessons we learn from modern, evolutionary minded theorists of justice is that effective social norms and rules will vary depending on the circumstances of the time and place. ${ }^{17}$ Once we see that Epicurean contractarianism can be consistent with Epicurean practical rationality, that is, once we see that justice can be instrumentally valuable to the pursuit of ataraxia, the individual Epicurean will have a self-interested reason to obey the constraints of justice. The Epicurean social contract, then, is possible. The question remains,

required by practical rationality to disobey the rules of justice. Some of the replies here to Cicero and Glaucon will apply to this question, though a full response would require more work.

${ }^{17}$ For a sophisticated recent attempt to deal with this problem, see: (Vanderschraaf 2010). Epicurus also makes this point in $K D 36$. 
however, why Epicureans need a social contract. If justice is consistent with practical rationality, first-personal practical rationality should be enough. To see why the Epicurean social contract is both possible and necessary we need to look at the specifically social role that the contract plays in coordinating and assuring members of society.

\section{The Necessity of the Contract}

The question of this section is why justice must be the result of a social compact and not merely part of the successful application of first-personal practical rationality, why justice, for the Epicurean, must be social rather than a merely personal virtue. I will argue that the social contract is necessary for three reasons: 1) it coordinate actions between members of a society 2) it helps create assurance that everyone in the society will follow the rules of justice 3) it specifies those rules to avoid ambiguity. These are the coordination, assurance, and specification functions of the social contract, respectively. None of these social functions can be accomplished by the separate, individual use of practical rationality.

The problem that the Epicurean social contract solves is not the same problem that the Hobbesian contract seeks to solve. The problem in Hobbes's state of nature is that natural equality leads to everyone believing that they can trample over others to achieve their ends (Leviathan, chap. 13). They overestimate their strengths as well as the benefits of conflict, while underestimating their weaknesses as well as the costs of conflict. Strife is the norm. The Epicurean contractor is not motivated by a desire to overpower or avoid others, but rather is driven by a desire to seek the means of mutual accommodation to avoid conflict 
in order to live blessedly. As we saw in $\S 2$ and $\S 3$, the Epicurean sees the rules of justice as a reliable way to secure tranquility. The rational Epicurean, however, will recognize that even if the social world is not necessarily characterized by strife in the way that Hobbes thinks, it is still characterized by confusion and misunderstanding. People would rather cooperate than fight, but if they are unsure, what others will do or unsure what the rules are, they will be afraid to cooperate. Furthermore, when disputes arise, there needs to be an impartial means to resolve disputes. Otherwise, the gains that might have come from cooperating and living with others, the benefits of commerce as well as friendship, will be lost.

Understood this way, we should model the Epicurean social contract as an assurance game. This type of strategic interaction models a social condition whereby individuals would most like to be able to coordinate and cooperate but are unsure how to do so and whether others will also cooperate. In contrast, the Hobbesian state of nature is a "mixed-motive game" like a prisoner's dilemma. In a mixed motive game, everyone will benefit from cooperation, but each person will also be tempted to defect from cooperation, universal defection, therefore, will be the dominant strategy. ${ }^{18}$ One version of a mixed-motive game, the prisoner's dilemma, is represented in Table 1 below with Roman numerals representing each prisoner's preference ranking (I is preferred to II and so on):

\section{Table 1}

\section{Prisoner 2}

Not Confess Confess

\footnotetext{
${ }^{18}$ For a canonical description of the prisoner’s dilemma see: (Luce and Raiffa 1957, §5.4).
} 


\begin{tabular}{|c|c|c|c|}
\hline \multirow{2}{*}{ Prisoner 1} & Not Confess & II, II & $\mathrm{IV}, \mathrm{I}$ \\
\hline & Confess & I, IV & III, III \\
\hline
\end{tabular}

In a two-person prisoner's dilemma, both prisoners are better off if they cooperate and do not confess. This solution is not stable, however. Each is better if they confess while the other stays silent. If they both reason this way, as they will if they are rational, they will be both led to the \{confess, confess $\}$ equilibrium, which is stable. The moral of the mixed-motive game is a tragic one. In this case, the exercise of individual practical rationality leads to an outcome that either party would have preferred to avoid. The only way to make cooperation rational in a prisoner's dilemma is to transform each player's payoffs in the game and thereby to transform the prisoner's dilemma into some other game where cooperation can be rational. ${ }^{19}$ The only way to win in a prisoner's dilemma, in short, is not to play at all. The question becomes, then, how to transform mixed-motive games where cooperation is difficult or impossible into coordination games where cooperation is possible and beneficial. The Epicurean social contract makes cooperation between practically rational agents possible and stable by transforming mixedmotive games into coordination games. To see how this process works, though, we need have a basic understanding of assurance games. ${ }^{20}$

\footnotetext{
${ }^{19}$ This is a point that informs much of Cristina Bicchieri's recent work on social norms. See: (Bicchieri 2006, chap. 1).

${ }^{20}$ An assurance game is a kind of impure coordination game. On the assurance problem, see: (Sen 1967) and (Baier 1995, chap. 5).
} 
Unlike mixed-motive games, assurance games typically involve multiple equilibria. In some cases, one equilibria is more beneficial (payoff-dominant), while the other is less risky (risk-dominant). The classic example is the stag hunt. In a stag hunt, players can chose to either hunt hare or stag. If both decide to hunt stag, they both benefit the most. If one decides to hunt stag and the other decides to hunt hare, the hare hunter gains and the stag hunter gets nothing because it takes two people to effectively hunt stag. One version of this game is represented below in Table 2 again with ordinal pay-offs represented by Roman numerals:

Table 2

\section{Hunter A}

\begin{tabular}{ll|l|l|}
\multicolumn{1}{c}{} & \multicolumn{1}{c}{ Hunt Stag } & \multicolumn{1}{l}{ Hunt Hare } \\
\cline { 3 - 4 } Hunter $B$ & Hunt Stag & I, I & III, II \\
\cline { 3 - 4 } & Hunt Hare & II, III & II, II \\
\cline { 3 - 4 } & &
\end{tabular}

The game has two pure equilibria (in bold): both hunt stag and both hunt hare. The problem is that the players will only hunt stag only if they trust that the other player will hunt stag, otherwise they will hunt hare. The problem that the Epicurean social contract solves is a stag hunt not a prisoner's dilemma. On this point I agree with Mitsis (Mitsis 1988, p. 81-82) that Denyer and Bailey are mistaken when they model the Epicurean contract as a solution to a prisoner's 
dilemma (Denyer 1983; Bailey 1928). I have already shown why this is the case in $\S 2$ and $\S 3$. Epicureans see effective rules of justice as a reliable means to ataraxia. A world where the Epicurean can be secure in the knowledge that they neither will harm nor be harmed by others is the most tranquil and prosperous kind of world (KD 33).

We are now in a position to see why the social contract is necessary to ensure mutual safety and cooperation. If the state of nature is a stag hunt, the problem is how to move from the risk-dominant equilibrium \{hare, hare to the payoff-dominant equilibrium $\{$ stag, stag $\}$ (Skyrms 2004, p. 9-13). Unless there is assurance that everyone else will hunt stag, each player will take the less risky strategy and hunt hare. If everyone hunts hare, however, society will be worse off than it might have been. The key to solving this problem is to develop a means to reliably indicate that everyone is planning to hunt stag rather than hare. As many recent thinkers have suggested in their different ways, the social contract understood as a set of norms or rules can be mechanisms for creating the public, social assurance that is necessary for mutual cooperation (Skyrms 2004; Bicchieri 2006; Binmore 2005; Smith 2008; Gintis 2009; Gaus 2011). These rules and norms make social coordination possible by facilitating mutual gain from cooperation. The mere presence of a suitably enforced contract can create the conditions that allow for justice and mutual benefit. ${ }^{21}$ Epicurean contractors can

\footnotetext{
${ }^{21}$ Herbert Gintis gives a different, though similar method of using social norms to solve mixedmotive and coordination games that involves transforming the original game into a super-game with another player, the choreographer who makes a move before all of the other players. See:
} (Gintis 2010). 
help to solve the mutual assurance problem by making clear, reasonable rules of justice that both Epicureans and non-Epicureans will have reason to follow because of the benefits that these rules secure. By contracting with one and other, Epicureans can make it possible for non-Epicureans to join the contract by fixing norms, making a public commitment to mutual assurance. There is still, however, an important role for punishment to play in stabilizing the social contract. While non-Epicureans will, no doubt, see the benefits of cooperating with the Epicureans along contractual lines, given the imperfections in their practical reasoning, they will still likely be tempted to cheat and disobey the rules of justice when they can get away with it. Punishment can help deter non-Epicureans from breaking the rules by increasing the cost and decreasing the benefit of cheating. Epicurus makes this point himself in $K D$ 34. Punishment can stabilize the social contract and preserve cooperation (Boyd and Richerson 2005).

A suitably enforced set of rules is not only necessary to prevent cheating by non-Epicureans, however. Consider, for instance, the case of a society made up of wise Epicureans..$^{22}$ Even in that kind of society, the social contract would be necessary. ${ }^{23}$ Epistemic and factual differences will lead each person to pursue different goals in different ways. Their conceptions of how to attain ataraxia as a

\footnotetext{
${ }^{22}$ For more on the important coordinating function of justice in Epicurean contractarianism which parallels many of the arguments made here in a different way, see: (O'Keefe 2001b).

${ }^{23}$ My discussion on this point shares some similarities with a theme of Gregory Kavka's work. The general idea that he and I both share is that, in his words, “....interpersonal conflicts... are not — as is often thought—simply a result of the immorality of the parties involved. Rather, they are at least partly the result of independent parties pursuing morally legitimate aims in a situation whose structure leads them into conflict" (Kavka 1995, p. 18).
} 
practical matter will not be identical. Even when two parties have the same motivation or the same ends, to coordinate each party needs to believe that the other party will actually do their part when their time comes (Skyrms 2001, p. 3233). One way to create this belief is to explicitly contract and to create enforcement mechanism that ensure everyone will do his or her duty. This is essentially the Hobbesian solution, to use punishment to secure compliance. The problem with this, from the Epicurean point of view, is that a sovereign powerful enough to protect and enforce compliance through punishment is also powerful enough to oppress. In addition to the previous problems of coordination, assurance, and specification, this solution creates the new problem of how to ensure protection from the sovereign. The main reason that Hobbes needs such a strong sovereign is that the Hobbesian state of nature is a prisoner's dilemma. As I have argued, however, that is not the situation in the world as conceived by the Epicureans. The problem that the social contract solves, for the Epicurean, is an assurance problem, not a mixed-motive problem. The role of the social contract then is to facilitate coordination and cooperation by specifying the rules of justice in a way that can lead to mutual assurance.

We get a picture of how the creation of an Epicurean social contract consisting of social rules and norms could arise in Lucretius's description of the evolution of the social contract In Book V of De Rerum Natura. ${ }^{24}$ There, Lucretius describes a natural state where, "each had to fight against all in an endless struggle for food, water, and minimal comfort" (DRN, V.839-840) and in the

\footnotetext{
${ }^{24}$ All excerpts from Lucretius taken from the 2008 Slavitt translation of De Rerum Natura, see: (Lucretius 2008).
} 
night men and beasts would prey upon one another while the weak cowered in fear. ${ }^{25}$ This is the mixed-motive nightmare of the Hobbesian state of nature. Eventually, though, men and women devise lodgings and begin to marry (DRN, V.878-885). Families band together to hunt more effectively and to protect their women and children while they are hunting (DRN, V.889-900). At this point, we can already see the basis of the transformation from the mixed-motive situation to a state of nature where assurance is the primary problem. It is the desire for companionship and family as well as the benefits of social hunting that transforms the mixed-motive problem into an assurance problem. Unlike the Hobbesian state of nature, which is full of fear and envy, this state of nature is characterized by the Epicurean desire for friendship and mutual benefit.

Once we understand the problem that the social contract solves as an assurance problem rather than a mixed-motive problem, we can clearly see why the Epicurean social contract is necessary. It is necessary because it fulfills the coordinating, assuring, and specification functions important to creating a stable general commitment to coordinate on the pay-off dominant rather than the riskdominant equilibrium. Only a public, social contract can preform this function. The individual use of practical rationality would not be able to fulfill these coordinating, assuring, and specifying functions.

\section{Epicurean Contractarianism}

Like many modern contractarians who followed him, Epicurus recognized that justice is necessary and desirable because of the benefits it brings and for no other 
reason. The social contract is the embodiment of justice as mutual benefit. The question for the Epicurean, the question that we began with, is whether the conception of justice as mutual benefit is compatible with Epicurean hedonism. Is it possible to reconcile justice and pleasure?

I have argued that the social contract is the means of reconciling justice and pleasure. For this to be a plausible strategy, however, required answering three basic questions. First, how is it possible for the Epicurean practical rationality to be governed by the rules in general? Second, if the first question was answered, how is the social contract possible given that justice may require individuals to sacrifice some pleasure in order to maintain the rules of justice? Third, even if the social contract is possible, why is it necessary from an Epicurean point of view? I answered the first question in $\S 2$ by arguing that Epicurean practical rationality is a form of "rule hedonism." Epicureans apply the hedonic calculus, at least some of the time, to rules rather than to actions or desires. Once we recognize that Epicureans are rule followers, it is a simple next step to show that it is possible for them to follow rules of justice, even when individual applications of those rules might be costly. In $\S 3$, I argued that Epicurean practical rationality, understood as rule-hedonism, is consistent with the demands of justice and that Epicureans can be reliably expected to abide by the demands of justice. Even if it is possible for Epicureans to follow the rules of justice, it is still an open question of whether those rules are actually necessary. That is, does the social contract fulfill an important function that the individual use of practical rationality cannot fulfill? In $\S 4, \mathrm{I}$ argued that a social contract is necessary because of the coordinating, assuring, and specifying role that it plays. 
Once we see that the Epicurean social contract is both possible and necessary, given the starting point of Epicurean practical rationality, we are left with the further question of whether this particular reconciliation of justice and pleasure is appealing. I will conclude with this question. The ultimate motivation for Epicurean contractarian is knowledge that life is fleeting. As Epicurus writes, "We are born only once, and we cannot be born twice; and one must for all eternity exist no more. You are not in control of tomorrow and yet you delay your opportunity to rejoice" (VS 14). Too much of history is the chronicle of lives destroyed and wasted in pursuits that enriched one life at the expense of another. The Epicurean vision of the just and good society is one where people are secure to freely pursue the ends they find valuable and to enjoy what little of life one has left without pain and fear and in the company of friends. The business of justice is to allow us to get on with the, all too short, business of living. As Hume wrote in his essay "The Epicurean" the motivating idea of this approach are the recognition of the frailty and the ephemeral nature of our own existence. Hume writes:

if life be frail, if youth be transitory, we should well employ the present moment, and lose no part of so perishable an existence. Yet a little moment and these shall be no more. We shall be, as if we had never been. Not a memory of us be left upon earth; and even the fabulous shades below will not afford us a habitation. Our fruitless anxieties, our vain projects, our uncertain speculations shall all be swallowed up and lost. Our present doubts, concerning the original cause of all things, must never, alas! be resolved. This alone we may be certain of, that, if any governing 
mind preside, he must be pleased to see us fulfill the ends of our being, and enjoy that pleasure, for which alone we were created. (Hume 1985/1742, Essay XV "The Epicurean")

Epicurean justice is an attempt to give an account of the rules that govern our interaction so that we may "enjoy that pleasure, for which we are alone created." If one finds this conception of the good society and the good life compelling, one will also find this kind of contractarian approach to justice appealing. Regardless, the real value and novelty of his theory is that he took the need to justify constraints on the individual pursuit of the good seriously. It is for that reason that his theory is still worthy of serious study. 


\section{References}

Annas J (1993) The Morality of Happiness. Oxford University Press, New York

Baier K (1995) The Rational and the Moral Order: The Social Roots of Reason and Morality. Open Court Publishing Company

Bailey C (1928) The Greek Atomists and Epicurus: A Study. Clarendon Press, Oxford

Bicchieri C (2006) The Grammar of Society: The Nature and Dynamics of Social Norms.

Cambridge University Press

Binmore K (2005) Natural Justice. Oxford University Press, New York

Boyd R, Richerson PJ (2005) Punishment Allows the Evolution of Cooperation (or Anything Else) in Sizable Groups. The Origin and Evolution of Cultures. Oxford University Press, pp $166-188$

Brown E (2009) Politics and Society. Cambridge Companion to Epicureanism

Cicero MT (2001) On Moral Ends. Edited by Julia Annas and Translated by Raphael Woolf. Cambridge University Press

Denyer N (1983) The Origins of justice. In: Macchiaroli G (ed)Syzetisis: studi sull'Epicureismo Greco e Romano offerti a Marcello Gigante. Naples, pp 133-152.

Evans M (2004) Can Epicureans Be Friends? Ancient Philosophy 24:407-424.

Gaus G (2011) The Order of Public Reason: A Theory of Freedom and Morality in a Diverse and Bounded World. Cambridge University Press

Gauthier D (1969) The Logic of Leviathan: The Moral and Political Theory of Thomas Hobbes. Oxford University Press, Oxford

Gauthier D (1982) Three against Justice: The Foole, the Sensible Knave, and the Lydian Shepherd. Midwest Studies In Philosophy 7:11-29.

Gauthier D (1986) Morals By Agreement. Clarendon Press, Oxford

Gigerenzer G, Goldstein DG (1996) Reasoning the Fast and Frugal Way: Models of Bounded Rationality. Psychological Review 103:650-669.

Gintis H (2009) The Bounds of Reason: Game Theory and the Unification of the Behavioral Sciences. Princeton University Press

Gintis H (2010) Social Norms as Choreography. Politics, Philosophy, and Economics 9:251-264.

Gough JW (1957) The Social Contract: A Critical Study of its Development, 2nd ed. Oxford University Press

Hampton J (1991) Two Faces of Contractarian Thought. In: Vallentyne P (ed)Contractarianism and Rational Choice: Essays on David Gauthier's Morals By Agreement. Cambridge University Press, Cambridge, pp 31-55 
Hampton J (1986) Hobbes and the Social Contract Tradition. Cambridge University Press

Hobbes T (1996) Leviathan. Revised Student edition. Cambridge University Press.

Hume D (1998) An Enquiry concerning the Principles of Morals. Oxford University Press.

Hume D (1985) Essays: Moral, Political, and Literary, Revised. Liberty Fund Inc.

Inwood B, Gerson LP (1994) The Epicurus Reader: Selected Writings and Testimonia. Hackett Publishing Company

Kavka GS (1984) The Reconciliation Project. In: Copp D, Zimmerman D (eds)Morality, Reason and Truth: New Essays on the Foundations of Ethics. Rowman \& Allanheld, pp 297-320

Kavka GS (1986) Hobbesian Moral and Political Theory. Princeton University Press

Kavka GS (1995) Why Even Morally Perfect People Would Need Government. Social Philosophy \& Policy 12:1-18.

LeBar M (2009) Virtue Ethics and Deontic Constraints. Ethics 119:642-671.

Luce RD, Raiffa H (1957) Games and Decisions: Introduction and Critical Survey. John Wiley \& Sons, New York

Lucretius (2008) De Rerum Natura: A Poetic Translation. Translated by David Slavitt. University of California Press

Mitsis P (1988) Epicurus’ Ethical Theory: The Pleasures of Invulnerability. Cornell University Press

Nikolsky B (2001) Epicurus on Pleasure. Phronesis 46:440-465.

O’Keefe T (2001a) Is Epicurean Friendship Altruistic? Apeiron: A Journal for Ancient Philosophy and Science 34:269-305.

O’Keefe T (2001b) Would a Community of Wise Epicureans Be Just? Ancient Philosophy 21:133-146.

Plato (1968) The Republic Of Plato. Translated by Allan Bloom. Basic Books

Schmidtz D (1992) Rationality within Reason. Journal of Philosophy 89:445-466.

Sen AK (1967) Isolation, Assurance and the Social Rate of Discount. The Quarterly Journal of Economics 81:112-124.

Skyrms B (2004) The Stag Hunt and the Evolution of Social Structure. Cambridge University Press

Skyrms B (2001) The Stag Hunt. Proceedings and Addresses of The American Philosophical Association 75:31-41.

Smith V (2008) Rationality in Economics: Constructivist and Ecological Forms. Cambridge University Press, Cambridge

Vander Waerdt PA (1987) The Justice of the Epicurean Wise Man. The Classical Quarterly 37:402-422. 
Vanderschraaf P (2010) The Invisible Foole. Philosophical Studies 147:37-58.

Vlastos G (1941) Slavery in Plato's Thought. The Philosophical Review 50:289-304. 